\title{
Research on Seismic Behavior of Semi-rigid Steel Frame Structures With Eccentric Brace
}

\author{
Peng Deng ${ }^{\star 1, a}$, Yingjuan Ma ${ }^{2, b}$,Xiaotong Shang ${ }^{2, c}$, \\ ${ }^{1}$ Shandong Provincal Key Laboratory of Civil Engineering Disaster Prevention and Mitigation, \\ Shandong University of Science and Technology, Qingdao, Shandong, 266590, China \\ ${ }^{2}$ College of Civil Engineering and Architecture, Shandong University of Science and Technology \\ Qingdao, Shandong 266590, China \\ adengpeng1226@163.com, b1040786498@qq.com , c173296033@qq.com,
}

Keywords: semi-rigid steel frame, joint stiffness, eccentric brace.

Abstract. Eccentric brace was used in the semi-rigid steel frame to improve the lateral rigidity as the steel frame has poor lateral displacement resisting ability and large deformation under the seismic action in spite of its better energy dissipation and seismic performance [1-10]. The elastic analysis under frequent earthquake and elastic-plastic analysis under rare occurrence earthquake of semi-rigid steel frames with no support, single-inclined eccentric support and herringbone eccentric support are all covered in this paper. The tpo displacement of each specimen and maximal floor shear changing law are analyzed. The change of the joint stiffness, the setting and type of the eccentrical brace and the influence on the dynamic performance of the semi-rigid steel frame are summarized. Research results in this paper are useful for the design of relevant structures on earthquake resistance and disaster mitigation.

\section{Introduction}

Semi-rigid connection has better energy dissipation capacity, seismic performance and plastic deformation capacity, but the low lateral rigidity, the weak lateral resisting ability and large deformation under seismic action may have bad effects on normal usage of the structure[1-3]. The most effective method is using lateral displacement resistant construction. Eccentrical brace is a new type of bracing system which not only remedies the defects of semi-rigid steel frames but also shows a better seismic performance[4-10]. The seismic performance of eccentrically braced semi-rigid steel frames were analyzed on the basis of research results at home and abroadin this paper. The results are useful for the design of relevant structures on earthquake resistance and disaster mitigation.

\section{The establishment of the models}

As shown in Fig.1, the two-story steel structures with end plates connections without support, with single-inclined eccentric support and with herringbone eccentric support are divided into three groups which are represented by $\mathrm{N}, \mathrm{X}$ and $\mathrm{Y}$ respectively. The span of structure is $6 \mathrm{~m}$, storey height is $3.6 \mathrm{~m}$, and welded $\mathrm{H}$ shaped steel of Q345 was used. The section dimensions of the column, the beam and the brace are $\mathrm{H} 300 \times 250 \times 8 \times 12, \mathrm{H} 300 \times 200 \times 8 \times 12$ and $\mathrm{H} 200 \times 150 \times 8 \times 10$ respectively. The type of site is II, the intensity of earthquake is 8 and the damping of each vibration model is 0.05 . Each group of model concludes three semi-rigid steel frames and one rigid frame. The initial rotational stiffness of three semi-rigid steel frames are $\mathrm{R} 1=33439 \mathrm{kN} \cdot \mathrm{M} / \mathrm{rad}, \mathrm{R} 2=54165 \mathrm{kN} \cdot \mathrm{M} / \mathrm{rad}$, $\mathrm{R} 3=100350 \mathrm{kN} \cdot \mathrm{M} / \mathrm{rad}$ respectively. The models are all under the same load.

\section{Analysis of influence on seismic behavior of the structure under frequent earthquake}

Top displacement analysis of models. EL-centro seismic wave is used to simulate the response of the structures under earthquake. The maximum top displacement in EL-wave was shown in Table 1. As shown in Table 1, the maximum top displacement of semi-rigid steel structure without support 
increased obviously compared with that of rigid steel structure. The maximum top displacement increased with the decrease of initial rotational stiffness. The maximum top displacement of eccentrically braced steel frame decreased obviously compared with that of unbraced steel frame.The effect of joint stiffness in the eccentrically braced steel frames can be ignored. The extreme displacement values increase with the decrease of the rotation stiffness in all steel frames. The extreme displacement values reached the maximum when $\mathrm{R} 1=33439 \mathrm{kN} \cdot \mathrm{M} / \mathrm{rad}$. The maximum top displacement in the single-inclined eccentric braced structure has little difference from that in the herringbone eccentrically braced structure when the load is equal. This shows that the effects of the ingle-inclined eccentric brace and the herringbone eccentric brace are similar.

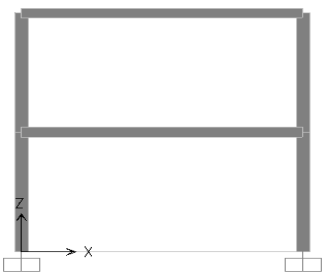

(a)

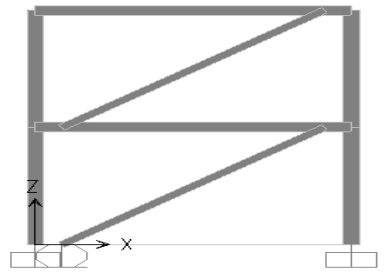

(b)

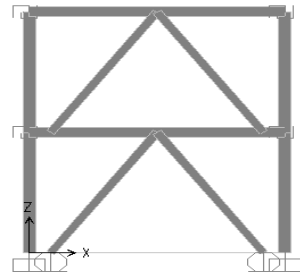

(c)

Fig. 1 Finite elements model of steel structures

$\begin{array}{lll}\text { (a) steel structure without support } & \text { (b) steel structure with single-inclined eccentric support }\end{array}$

(c) steel structure with herringbone eccentric support

Table 1 Maximum top displacement of structures

\begin{tabular}{c|c|c|c|c}
\hline Brace type & R1 & R2 & R3 & R4 \\
\hline N series & 152.1 & 139.4 & 125.3 & 87.4 \\
\hline X series & 72.1 & 79.7 & 72.3 & 64.8 \\
\hline Y series & 72.4 & 73.3 & 74.6 & 63.5 \\
\hline
\end{tabular}

Maximum story shear of structures. Maximum story shear of all structures in EL-wave are shown in Fig.2 to Fig.4. From the figures, the story shear curves of $\mathrm{N}$ series with semi-rigid connections are smooth, and story shears decrease obviously with the decrease of the connection stiffness. Maximum shears appear at the bottom. Story shears of $\mathrm{X}$ series with semi-rigid connections are approximate, which are slightly larger than those of structures with rigid connection, and joint stiffness has little influence on the story shear. For Y series, the effect of the joint stiffness on the story shear is irregular, and story shears of structures with semi-rigid connections are slightly larger than those of structures with rigid connections. Therefore, joint stiffness has significant influence on the story shear of structures without support, but has little influence on that with eccentric brace. And eccentric brace has significant influence on the story shear of structures, which shows that eccentric brace can improve the integral rigidity of structures effectively with the result that the structures can absorb more seismic energy which makes the story shear increase.

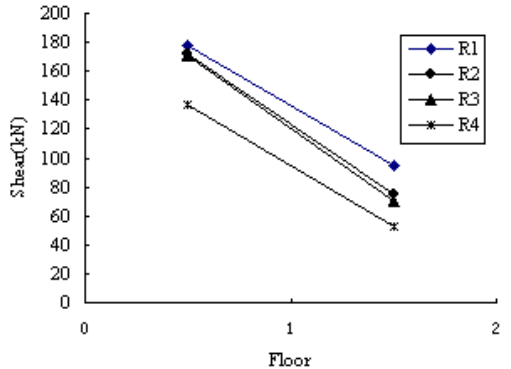

Fig.2 Maximum story shear of $\mathrm{N}$ series

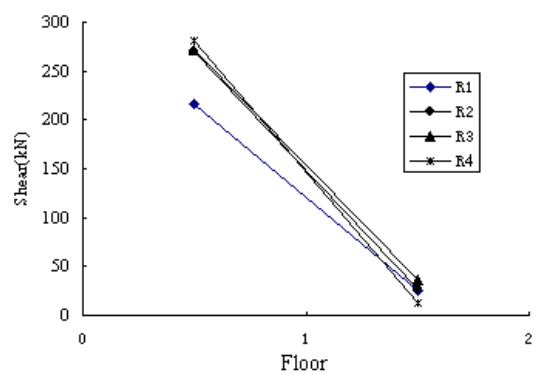

Fig.3 Maximum story shear of X series 


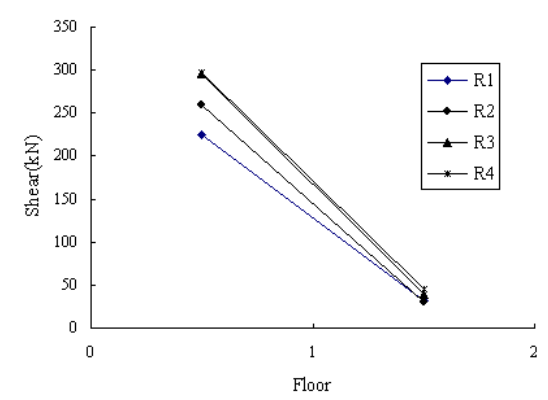

Fig.4 Maximum story shear of Y series

Maximum top displacement of frame in different braces. Maximum top displacements of frames in different braces are shown in Fig.5. The inter-story displacements of $\mathrm{N}$ series are always larger than those of $\mathrm{X}$ series and $\mathrm{Y}$ series except rigid frames. For the rigid frames, the top displacement in the first floor of $\mathrm{N}$ series is smaller than those of $\mathrm{X}$ series and $\mathrm{Y}$ series, but that in the second floor is on the contrary. So the eccentric brace could reduce the top displacement effectively and improve the integral rigidity.

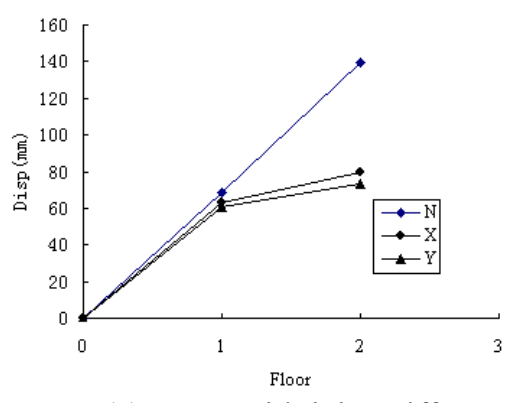

(a)Frame with joint stiffness of

$54165 \mathrm{kN} \cdot \mathrm{M} / \mathrm{rad}$

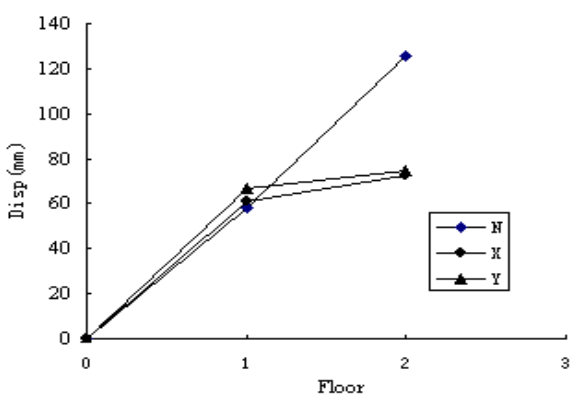

(c) Frame with joint stiffness of $100350 \mathrm{kN} \cdot \mathrm{M} / \mathrm{rad}$

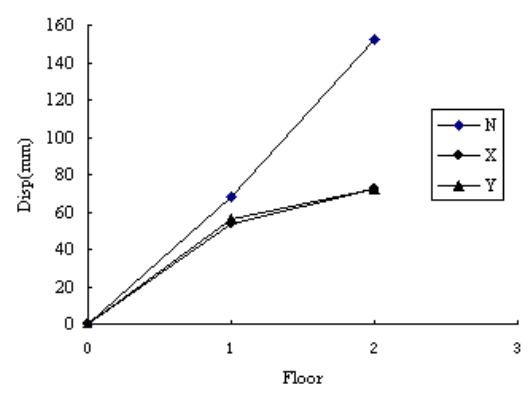

(b) Frame with joint stiffness of $33439 \mathrm{kN} \cdot \mathrm{M} / \mathrm{rad}$

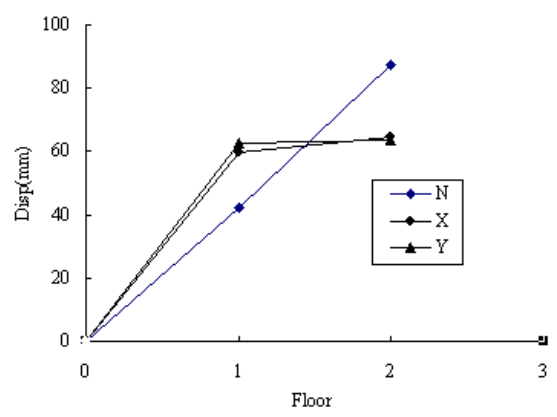

(d) Rigid frame

Fig.5 Maximum top displacement of frames in different braces

\section{Analysis of the response of the structure under rare earthquake}

Semi-rigid connections have better energy-dissipating capacity and can consume most earthquake energy under strong earthquakes. EL-centro seismic wave was used to simulate the response of structures under rare earthquakes. The comparison for energy dissipation of semi-rigid frames with different joint stiffness is shown in Table 2. From the table, all the semi-rigid connections could consume most energy. The energy dissipation ratios of X-2-R1 and Y-2-R1 are $90.28 \%$ and $90.61 \%$ respectively, but that of $\mathrm{N}-2-\mathrm{R} 1$ is only $75.55 \%$, which shows that the frames with eccentric braces have better energy-dissipating capacity than those without support. The energy dissipation ratios of $\mathrm{X}-2-\mathrm{R} 3$ and $\mathrm{Y}-2-\mathrm{R} 3$ are $95.42 \%$ and $94.83 \%$ respectively, which shows that the energy-dissipating capacity of these two models is similar. From the data, conclusion can be made that the energy-dissipating capacity of eccentrically braced semi-rigid steel frames is better and the two types of the eccentric brace have similar energy-dissipating capacity. 
Table 2 Comparison for energy dissipation of semi-rigid connections

\begin{tabular}{c|c|c|c}
\hline Structure type & $\begin{array}{c}\text { Energy input of } \\
\text { earthquake }(\mathrm{kN} \cdot \mathrm{M})\end{array}$ & $\begin{array}{c}\text { Energy dissipation of } \\
\text { connections }(\mathrm{kN} \cdot \mathrm{M})\end{array}$ & $\begin{array}{c}\text { Energy } \\
\text { dissipation } \\
\text { ratio (\%) }\end{array}$ \\
\hline $\mathrm{N}-2-\mathrm{R} 1$ & 2904 & 2194 & 75.55 \\
\hline $\mathrm{N}-2-\mathrm{R} 3$ & 2060 & 1795 & 87.14 \\
\hline $\mathrm{X}-2-\mathrm{R} 1$ & 2798 & 2526 & 90.28 \\
\hline $\mathrm{X}-2-\mathrm{R} 3$ & 2360 & 2252 & 95.42 \\
\hline $\mathrm{Y}-2-\mathrm{R} 1$ & 3228 & 2925 & 90.61 \\
\hline $\mathrm{Y}-2-\mathrm{R} 3$ & 2667 & 2529 & 94.83 \\
\hline
\end{tabular}

\section{Conclusion}

The energy-dissipating capacity of semi-rigid connections could reduce the displacement under the earthquake load. Compared with the steel frames without support, those with single-inclined eccentric support and herringbone eccentric support have greater lateral stiffness and smaller lateral displacement, which shows that the eccentric braces enhance the energy-dissipating capacity and improve the ductility of structure. Thus the seismic bearing ability of the frames is improved, which is beneficial to earthquake resistance of structures.

\section{References}

[1] Shi Y J,Chan S L and Wong Y L. Modeling for moment-rotation characteristics forend-plate connections[J]. Journal of Structural Enginnering, ASCE, 1996,122(11):1300-1306

[2] Y. Xiao,B.S. Choo \& D.A. Nethercot. Composite connections in steel and concrete. I. Experimental behaviour of composite beam-Column connections [J]Journal of Constructional Steel Research, 1994,31(1) :3 30

[3] T. Q. Li, D. A. Nethercot \& B. S.Choo. Behaviour of flush end-plate composite Connections with unbalanced moment and variable shear-moment ratios-I.Experimental behaviour[J]. Journal of Constructional Steel Resear, 1996,38(2) :125 164

[4] Agerskov H.High-strength bolted connections subject to prying[J].ASCE Journal of the Structural Division, 1976,102 (ST1) : 161 175

[5] N.Kovacs. Experiment program on bolts on bolted end-plate joints of compositmembers[J].First International Conference on Steel \& Composite Structures:12 37

[6] Grundy P, Thomas I R,Bennetts I D.Beam-to-column moment connections[J]. Journal of thestructural Division, ASCE,1980,108(1):313 330

[7] Adey,B.T, Grondin,G.Y and Cheng,J.R. Cyclic Loading of End Plate Moment Canadian [J].Journal of Civil Engineering, 2000,27(4):683 701

[8] Yardimci N, yorgun $\mathrm{C}$,et al. Tests on beam-column strong and weak axis connection[J].Computers\&structures, 1996, 61(3):393 399

[9] Korol, R.M, Ghobarah,A and Osman,A. Extended end-plate connections under cyclic loadings:behavior and design[J].Construct. Steel Research 16(1990):253 280

[10] GildonC S,Uang C M.Cyclic response and design recommendations of weak axisreduced beam section moment connections[J].Journal of structural Engineering, 2002, 128(4):452 63 